\title{
FDG positron emission tomography of giant cell arteritis with polymyalgia rheumatica
}

\author{
Kiyoshi Shikino, Masatomi Ikusaka, Fumio Shimada
}

Department of General Medicine, Chiba University Hospital, Chiba, Japan

\section{Correspondence to} Dr Kiyoshi Shikino, kshikino@gmail.com

Accepted 19 February 2015

CrossMark

\section{To cite: Shikino $\mathrm{K}$,}

Ikusaka M, Shimada F. BMJ Case Rep Published online: [please include Day Month Year] doi:10.1136/bcr-2014206887

\section{DESCRIPTION}

An 80-year-old woman presented with low-grade fever, weight loss and shoulder ache persistent over 6 months. She had developed headache with scalp allodynia, though these had improved spontaneously within 2 months. Physical examination revealed an absent temporal artery pulse and decreased range of active shoulder motion. Laboratory findings showed a high erythrocyte sedimentation rate $(73 \mathrm{~mm} / \mathrm{h})$. Temporal artery ultrasonography revealed no halo sign, stenosis or occlusion. Fluorodeoxyglucose positron emission tomography (FDG-PET) showed increased uptake in the thoracic aorta and carotid and subclavian branches, and bilateral shoulder, hip, and interspinal regions in the lower thoracic and lumbar spine (figures 1 and 2). Giant cell arteritis

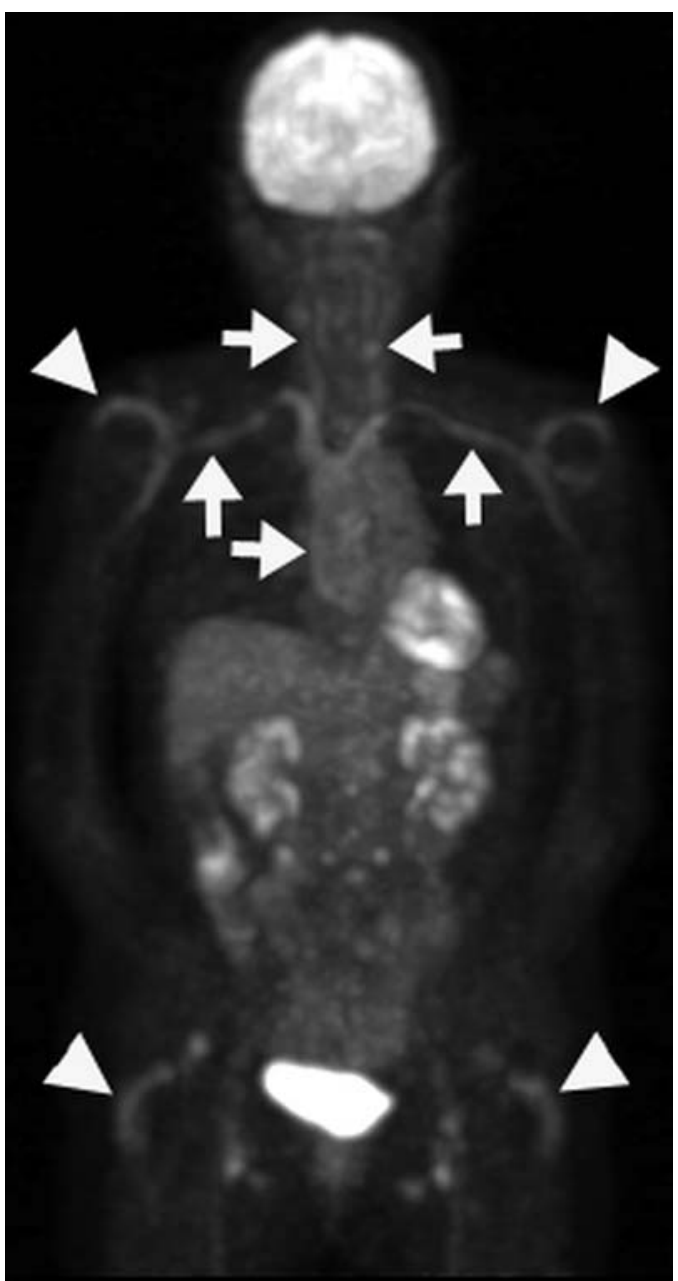

Figure 1 Fluorodeoxyglucose positron emission tomography image with arrows pointing towards abnormal uptake in the carotid and subclavian arteries as well as the thoracic aorta (arrows), and the bilateral shoulder and hip (arrowheads).
(GCA) with polymyalgia rheumatica was diagnosed. Symptoms improved with prednisolone $(30 \mathrm{mg} /$ day).

GCA is associated with chronic vasculitis of large vessels, primarily the aorta and its main branches. It occurs in individuals aged $>50$ years. Polymyalgia rheumatica is closely linked to GCA, occurring in about $40-50 \%$ of patients. Headache is present in $90 \%$ of cases, frequently accompanied by scalp allodynia. In some cases, the inflammatory process may

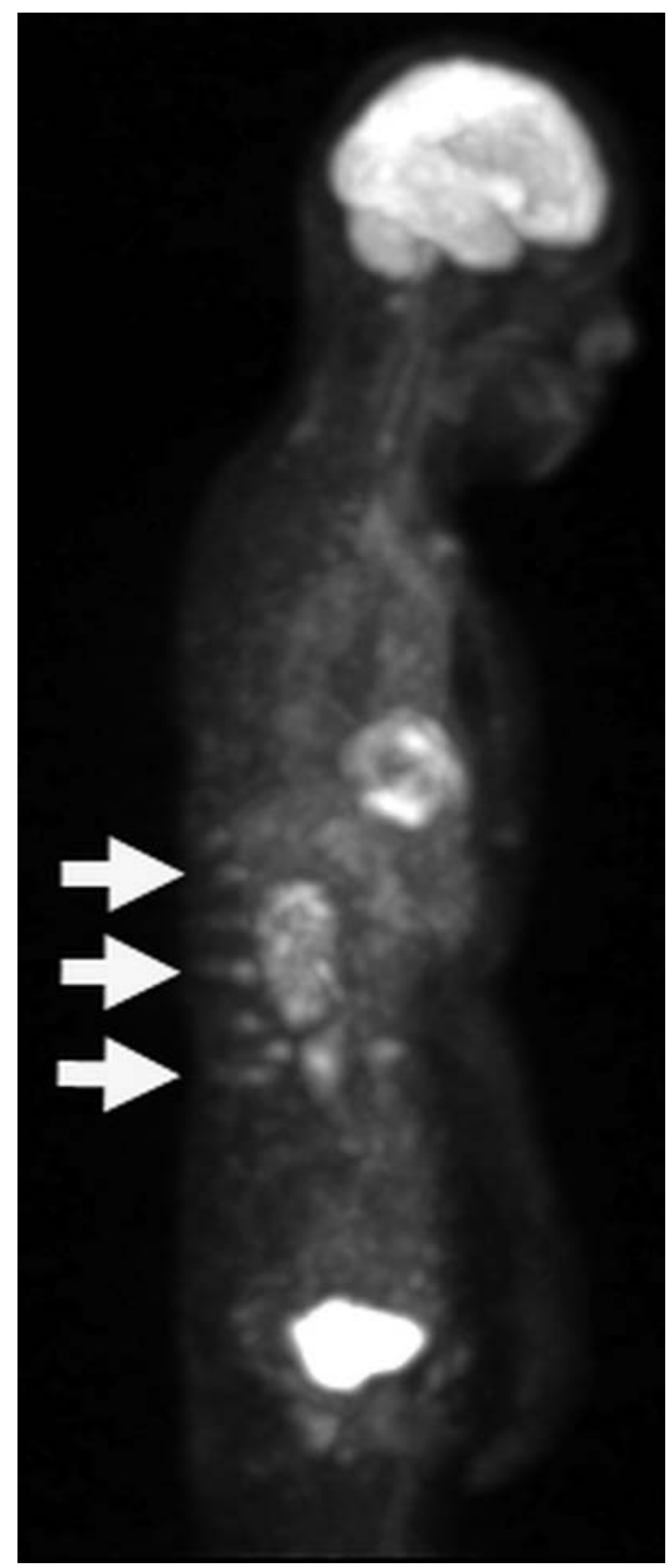

Figure 2 Fluorodeoxyglucose positron emission tomography image with an arrow pointing to abnormal uptake in the interspinal regions in the lower thoracic and lumbar spine (arrows). 
spontaneously become clinically silent, ${ }^{1}$ requiring clinicians to evaluate symptoms by direct questioning.

Temporal artery ultrasonography, one of the non-invasive tests, is helpful in diagnosing giant-cell arteritis (sensitivity $88 \%$ and specificity $78 \%) .{ }^{2}$ FDG-PET can be used to detect subclinical inflammation of large vessels in GCA. ${ }^{3}$ Although there is no perfect method for the diagnosis of GCA at present, FDG-PET may play a role in the management of GCA when the ultrasonography is negative.

\section{Learning points}

- Headache is present in $90 \%$ of giant cell arteritis (GCA) cases, frequently accompanied by scalp allodynia.

- The inflammatory process may spontaneously become clinically silent, requiring clinicians to evaluate symptoms by direct questioning.

- Fluorodeoxyglucose positron emission tomography may play a role in the management of GCA when the ultrasonography is negative.
Twitter Follow Kiyoshi Shikino at @K

Contributors All authors were involved in managing the patient. KS wrote the first draft. Ml edited the manuscript.

Competing interests None.

Patient consent Obtained.

Provenance and peer review Not commissioned; externally peer reviewed.

\section{REFERENCES}

1 Hernández-Rodríguez J, García-Martínez A, Espígol-Frigolé G, et al. Sustained spontaneous clinical remission in giant cell arteritis: report of two cases with long-term followup. Arthritis Rheum 2006;55:160-2.

2 Karassa FB, Matsagas MI, Schmidt WA, et al. Meta-analysis: test performance of ultrasonography for giant-cell arteritis. Ann Intern Med 2005;142:359-69.

3 Besson FL, Parienti JJ, Bienvenu B, et al. Diagnostic performance of ${ }^{18} \mathrm{~F}$-fluorodeoxyglucose positron emission tomography in giant cell arteritis: a systematic review and meta-analysis. Eur I Nucl Med Mol Imaging 2011;38:1764-72.

Copyright 2015 BMJ Publishing Group. All rights reserved. For permission to reuse any of this content visit http://group.bmj.com/group/rights-licensing/permissions.

BMJ Case Report Fellows may re-use this article for personal use and teaching without any further permission.

Become a Fellow of BMJ Case Reports today and you can:

- Submit as many cases as you like

- Enjoy fast sympathetic peer review and rapid publication of accepted articles

- Access all the published articles

- Re-use any of the published material for personal use and teaching without further permission

For information on Institutional Fellowships contact consortiasales@bmjgroup.com

Visit casereports.bmj.com for more articles like this and to become a Fellow 